\title{
Special Issue: Popular Music, Decolonization, and Indigenous Studies
}

\author{
Kirsten Zemke \\ University of Auckland \\ k.zemke@auckland.ac.nz
}

\author{
Arcia Tecun \\ University of Auckland \\ d.hernandez@auckland.ac.nz
}

\section{Introduction}

This Special Issue centers on the theme of decolonization. This is both an urgent and a fertile topic, with popular music providing a vital means for Indigenous activism, creativity, and celebration. Popular Music scholars engage with literature and theory from a range of locations, and it is heartening that the IASPM Journal has used this opportunity to signal to our community the importance of this particular locus. While of course we celebrate the engagement with Decolonization "theory" and the attention on Indigenous popular music practices and artists, we acknowledge that while we "play" in the discourse, colonization is a very real lived experience manifesting in outcomes of poverty, language loss, disease, and genocide. These material realities additionally impact who is, and who is not in the academy to tell these stories through popular music studies. Yet, despite this ongoing problem, through the accessibility of popular music, many of these stories are available through music and performance, which the scholars in this issue thoughtfully engage with directly. Decolonization is intertwined with and politically related to, feminism, queer studies, anti-ableism, anti-racism, the dismantling of white supremacy, and anti-capitalism; and these articles refer to many of these connections.

Indigenous studies scholars Eve Tuck and K. Wayne Yang (2012) have argued that decolonization is set apart from other social justice issues due to its additional imperative of "land back". Political scholars Sean Coulthard (2014) and Audra Simpson (2014) point to a decolonization that confronts an ongoing colonial project through the politics of refusal to settler-colonialism and recognition. Historian 
Gerald Horne (2018) explains that conquest in North America and the Caribbean was an apocalyptic project of both colonization and race. South American and Caribbean scholars such as Aníbal Quijano (2000), María Lugones (2007), Walter Mignolo (2011), Sylvia Wynter (2003), and Nelson Maldonado-Torres (2007) signal to a post-1492 matrix of power that gave rise to a global hegemonic order of race, gender, and capitalist colonial power that is both material and metaphysical. Native and Black Studies scholar Tiffany Lethabo King (2019) brings together different lineages of this modern formation of power to that which exceeds white settler colonial studies, pointing to the role of African and American Indian genocide and slavery in actualizing the modern world. We recognize that settler-colonial, decolonial, Native and Indigenous studies have been most prevalent in the North American region, as well as in scholarship from other settler-colonial nations. While this is critically significant, due to the North American, and specifically U.S. influence on world politics, a global approach, such as in this issue, broadens and complexifies further our modern, colonial world, as well as conceptualizations of Indigeneity.

Additionally, while this Special Issue highlights the paramount importance of Indigenous connections to land, Indigenous rights, justice, and restitutions, with a rich collection of work that spans across our planet-we also want to leave room open for the diverse constellation of Indigenous peoples and colonial/imperial projects not represented. Leaving room for those who may emphasize in their identities: place, time, mobility, and/or water. Academia itself has been a complicit perpetrator of colonial hegemony and horrors, with many of these institutions having been built through conquest, extraction, occupation, exclusion, and exploitation of the physical, intellectual, and emotional labour of Indigenous peoples. We hope that this Special Issue inspires our scholarship community to further interrogate our positions, and relationships to the lands, waters, skies, and peoples where we reside; the colonial legacies and powers of the nation's we reside in; and the planetary environmental and climate crises that we face collectively, albeit differently.

We are pleased to introduce the following articles that appear in this Special Issue that interrogate colonialism, internationalism, and popular music.

Przybylski in "Indigenizing the Mainstream: Music Festivals and Indigenous Popular Music" explores "Indigenous survivance" through what she calls "sonic sovereignty" which is the ability to frame how one is heard. She looked at First Nations, Métis, and Inuit music and dance practices at music festivals, especially the sākihiwē festival in Winnipeg. She found that the festivals are a launchpad for Indigenous artists, and a space for teaching, learning and sharing stories. Due to the timing of this edition, Przybylski also documented and tracked the effect that COVID had on the musicians and festivals, showing how they creatively adapted and responded to the crisis, which presents increased risks particularly to Indigenous folks. The festivals feature music and artists who engage with rock, hip hop, folk, pop, country, dance, and other genres with these forms utilized, reworked, and merged to "engage the hyper-local".

Allimant and Holas look at a 1970's Chilean Psychedelic Rock band Los Jaivas, showing how their incorporation of Indigenous ways of being decolonize mainstream conceptions of the Chilean subject (as Andean, not dis-placed European) and recognizes Indigenous values as a root of Chilean reality. They explore how the band employs the concept of Estar, from the ontology of Kichwa and Aymara peoples, which is about equalizing, living in balance with the forces of life. This exploration shows the flexibility of the popular music genre, which 
could be seen as a globalizing "outside", potentially recolonizing, hegemonic force, but has actually been used to decolonize conceptions of nation, identity, and self.

Werner, in "Feminist and Sámi politics in the music of Maxida Märak" looks at the 2019 pop/hip hop album of a one of the most well-known Sámi artists in Sweden. Werner utilizes an Indigenous feminist lens, exploring how Märak in her songs and videos explores themes and metaphor around land, motherhood, and climate change. This article offers that Swedish interest in environmental conservation issues, and engendered interest in Indigenous knowledge systems as useful for the conservation of the environment. The exploration of motherhood relates to a feminization of the land, and to mothers as the keepers of Indigenous knowledge systems, but Werner also relates this to a critique of neo-liberal society and the failures of capitalism.

The next article "Decolonizing the Boundaries: Indigenous Musical Discourse in the History of Kurdish Radio Baghdad" by Bullock engages with indigeneity discourse itself, as it has often ignored the Middle East, since the linear pattern of European settler colonialism and land displacement does not apply neatly in this region; neither do distinctions between popular musics and folks musics. The article offers the early history of Kurdish Radio Baghdad, an Iraqi state-operated broadcasting system in the 1920s and 30s, which, while "hostile to their very existence", offered a space for Iraqi Kurdish musicians to navigate, generate, and disseminate contemporary forms of mass-mediated Kurdish culture which are integral musical memories for today's Iraqi Kurdish culture and music.

Shuvera offers an account of Inuk popular music artist and throat singer, Tanya Tagaq, looking in particular at the artist's 2016 cover of Nirvana's "Rape Me", which in this version now speaks to the sexual violence of colonialism and the disturbing, continuing acts, and acceptance of rape, and sexual and gendered violence against Indigenous women. The album Retribution, in which Tagaq, from Cambridge Bay (Iqaluktuutiaq), Nunavut, covers "Rape $\mathrm{Me}^{\prime}$, is an activist statement; a refusal to accept the more generally considered reconciliation; and the cover song, which includes Tagaq's distinctive throat singing, reminds of and cries for the death and trauma that continue to occur under settler colonial systems. Shuvera also explores the implications around cross gender and cross "cultural" music covers, seeing Tagaq as "pushing settler listeners outside established listening experiences and states of mind".

The time, place, and genre diversity of this Special Issue offers a multiplicity of Indigenous experiences and relationships with colonialism and empire. The articles show a breadth of creative and political engagement by Indigenous folks with popular musical expressions. We would also like to thank the IASPM Journal Editor, Mary Fogarty, and Assistant Editor, Raquel Campos, along with the rest of the Editorial Board members for all of their work making this Special Issue possible.

In conclusion, we wanted to add our recommended reading list as a starting point for those wanting to engage further with the matters raised in this issue, but also as an acknowledgement of our sources of thought and inspiration:

Césaire, A. 1955. Discourse on Colonialism. Trans. Joan Pinkham (1972). New York: Monthly Review Press.

Cusicanqui, S. R. 2012. Ch'ixinakax utxiwa: A Reflection on the Practices and

Discourses of Decolonization. South Atlantic Quarterly 111(1): 95-109.

Fanon, F. -

1970. Black Skin, White Masks. London: Paladin. 
2004. Wretched of the Earth. Translated by Richard Philcox (1961). New York: Grove.

Freire, P. 1996. Pedagogy of the Oppressed (revised). New York: Continuum.

Mar, T. B. 2016. Decolonisation and the Pacific. Cambridge: Cambridge University Press.

Smith, L. T. 2021. Decolonizing Methodologies: Research and Indigenous Peoples. London: Zed Books Ltd.

Todd, Z. An Indigenous Feminist's take on the ontological Turn: 'Ontology' is just another Word for Colonialism. Journal of Historical Sociology 29(1): 4-22.

Wa Thiong'o, N. 1992. Decolonising the Mind: The Politics of Language in African Literature. Nairobi: East African Publishers.

Whyte, K. 2020. Too late for Indigenous Climate Justice: Ecological and Relational Tipping Points. Wiley Interdisciplinary Reviews: Climate Change 11(1/e603): 1-7.

Wolfe, P. 2006. Settler Colonialism and the Elimination of the Native. Journal of genocide research 8(4): 387-409.

\section{Bibliography}

Coulthard, G. S. 2014. Red Skin, White Masks: Rejecting the Colonial Politics of Recognition. Minneapolis: Minnesota.

Horne, G. 2018. The Apocalypse of settler Colonialism: The Roots of Slavery, white Supremacy, and Capitalism in 17th century North America and the Caribbean. New York: NYU Press.

King, T. L. 2019. The Black Shoals. Durham: Duke University Press.

Lugones, M. 2007. Heterosexualism and the Colonial/Modern Gender System. Hypatia 22(1): 186-219.

Maldonado-Torres, N. 2007. On the Coloniality of Being: Contributions to the Development of a Concept. Cultural studies 21(2-3): 240-270.

Mignolo, W. D. 2011. The Darker Side of Western Modernity. Durham: Duke University Press.

Quijano, A. 2000. Coloniality of Power and Eurocentrism in Latin America. International Sociology 15(2): 215-232.

Simpson, A. 2014. Mohawk Interruptus. Durham: Duke University Press.

Tuck, E, and Yang, K. W. 2012. Decolonization is not a Metaphor. Decolonization: Indigeneity, Education \& Society 1(1):1-40.

Wynter, S. 2003. Unsettling the Coloniality of Being/Power/Truth/Freedom:

Towards the Human, after Man, its Overrepresentation-An Argument. CR: The new centennial review, 3(3): 257-337. 